\title{
The Public Acceptance of Voluntary Childlessness in the Netherlands: from 20 to 90 per cent in 30 years
}

\author{
Suzanne Noordhuizen · Paul de Graaf • Inge Sieben
}

Accepted: 3 January 2010/Published online: 16 January 2010

(C) The Author(s) 2010. This article is published with open access at Springerlink.com

\begin{abstract}
Within a relatively short period of 30 years, public acceptance of voluntary childlessness has increased enormously in the Netherlands. In this paper, we address two research questions, which we answer with data from 13 waves of the repeated crosssectional survey Cultural Change in the Netherlands (CCN, 1965-1996). First, we investigate to what extent the increasing permissiveness is due to cohort replacement and to intra-cohort change. We find that between 1965 and 1980 the change is primarily due to intra-cohort (period) effects, whereas cohort replacement has become more important since 1980. Second, we address the question which social categories constitute the $10 \%$ of the population who do not accept voluntary childlessness. Church attendance-and not religiosity or religious socialization-turns out to be the most important factor. Low levels of income and education also negatively affect the acceptance of voluntary childless.
\end{abstract}

Keywords Social change · Voluntary childlessness · Public opinion ·

The Netherlands

\section{Introduction}

In this paper, we investigate sociological aspects of the rapid increase in the public acceptance of voluntary childlessness in the Netherlands. In the 1960 s, only $20 \%$ of the Dutch population accepted that a couple preferred to remain childless, and in the 1990s this proportion has increased to 90\% (Survey CCN 1965-1996, own calculations). This strong change in the social norms about family planning has gone together with declining fertility rates. International comparisons show that the decline in fertility has had a comparatively strong momentum in the Netherlands: In 1960 the Dutch fertility rate was above the European average and in 1980 it was below the European average (Castles 2003).

Childlessness concerns both social scientists and policy makers, and quite some research has focussed on the individual determinants and consequences of childlessness

S. Noordhuizen $(\bowtie) \cdot$ P. de Graaf $\cdot$ I. Sieben

Tilburg University, Tilburg, Netherlands

e-mail: s.c.c.a.noordhuizen@uvt.nl 


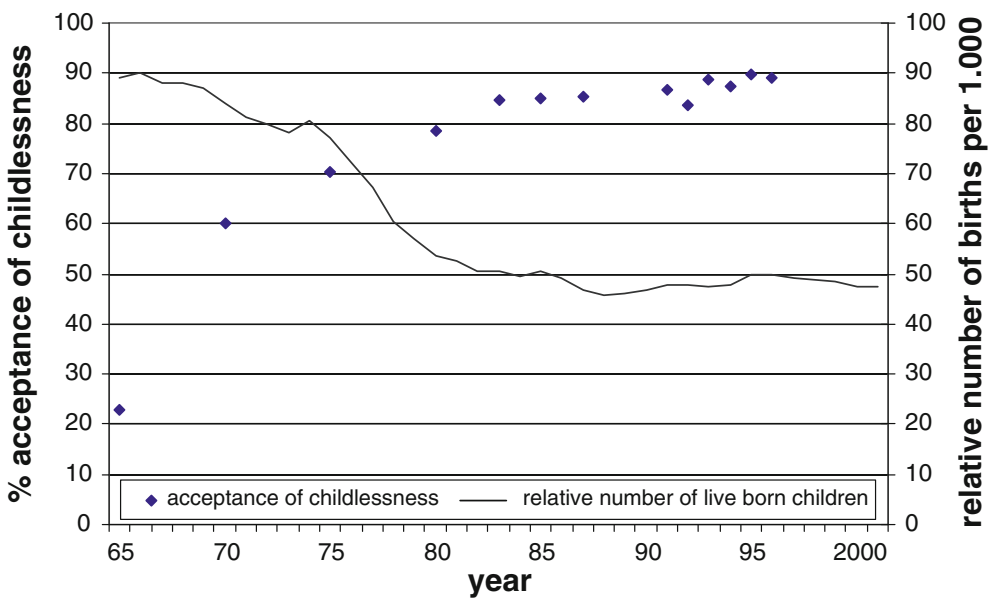

Fig. 1 Relative number of live born children $^{\mathrm{a}}$ (fertility behaviour) and acceptance of voluntary childlessness ${ }^{\mathrm{b}}$ (fertility attitudes) by survey year. ${ }^{\mathrm{a}}$ Relative number of live born children: The number of live born babies per thousand of the average number of women aged 15-50 in the period of observation. Live born child: A baby showing some sign of life after birth, regardless of the duration of pregnancy. Source Statistics Netherlands at www.cbs.nl/statline. ${ }^{\mathrm{b}}$ Source Cultural Change in the Netherlands (CCN) surveys

(cf. Dykstra and Hagestad 2007; Keizer et al. 2007; Koropeckyj-Cox and Call 2007). Others have been more interested in more general causes and consequences of increasing childlessness. Van de Kaa (1987) and Lesthaeghe (1995) interpreted the decline in fertility rates as part of a broad process of social change, which they labelled as the Second Demographic Transition. Important elements of this process are the rise of cohabitation as an alternative to marriage, the increasing age at motherhood, and the increase of divorce. These behavioural issues have followed similar patterns, and, importantly, have gone hand in hand with changes in values on fertility and family planning.

One of the most important instigators of the Second Demographic Transition is seen in the changing division of labour between men and women as a result of increases in women's educational attainment and in the growing permissiveness of the labour market participation of women, especially of mothers. The main argument is that rising levels of women's human capital have increased the costs of having children. Simultaneously, there has been technological innovation with regard to birth control and family planning. Contraceptive methods have become widely available, and parenthood has become more a choice than an almost unavoidable event (Hakim 2003).

The shifts in fertility behaviour and fertility norms in the Netherlands are shown in Fig. 1.The statistics display a sharp decline in the number of births in the Netherlands. The birth rate dropped from about 90 children per 1,000 women aged 15-50 years in 1965 to 50 children per 1,000 women in the 1980s. In the same period, the Dutch population has become more permissive towards voluntary childlessness, as indicated by the dots. The strong decline in norms is the object of our study. ${ }^{1}$

We address two research questions about the change in public support for voluntary childlessness in the Netherlands. First, we investigate whether the overall change has come

1 Moors (1996) has shown that fertility behaviour and fertility values are strongly correlated on the individual level as well. 
about by cohort replacement or by intra-cohort changes (cf. Firebaugh 1997). Cohort replacement explains (part of) the overall change if younger birth cohorts are more permissive towards voluntary childlessness than older birth cohorts. The underlying assumption is that values are socialized during childhood and early adulthood and are relatively resistant to change over the life-course (Inglehart 1977). Intra-cohort change would explain (part of) the overall change when members of some or allbirth cohorts become more permissive over a given time-span. Changes in the values of a birth cohort can come about by two processes, by period effects and by life-course effects. Period effects are effects of contextual nature that affect all people, young and old, in similar ways, like economic or political conditions. Life-course effects are age-dependent and have to do with personal development as affected by experiencing life events such as marriage, divorce, and having children.

Using repeated cross-sectional data-which is the research design we are using-makes it possible to distinguish between cohort replacement and intra-cohort effects, for intracohort change shows up as period effects in a regression model in which birth cohort is controlled for (Firebaugh 1997). It is important to note that the fast increase in the percentage of the Dutch population approving voluntary childlessness logically cannot be the result of cohort replacement only, since the part of the population that has been 'replaced' in a period of 30 years is not large enough to account for the major changes that have taken place. However, it remains very interesting to decompose the general trend into cohort replacement and intra-cohort changes, and in this paper we set out to answer this question.

The second research question we address in this study is about the declining part of the population who is not supporting voluntary childlessness. Nowadays, about $90 \%$ of the Dutch population approves a couple's decision to forgo parenthood. Who are the remaining $10 \%$ of the population who do not adhere to the modern value that the individual preference to remain childless should be respected? To answer this question, we explore differences in fertility values with respect to gender, family structure, educational attainment, income, and urbanization, and we pay special attention to differences between the religious and the non-religious parts of the population. Within the religious part of the population we will investigate differences between the three major denominations in the Netherlands (Roman Catholics, Dutch Reformed, and Re-reformed), and differences between churchgoers and those who do not visit church on a regular basis.

By answering these two questions, we hope to gain more insight in the rapid change in values towards voluntary childlessness. We think that doing research on this topic is important because of two reasons. First, there is the scholarly fascination to study an attitude that has changed so fast in such a short period. Second, the origins of social change for this value are important for society and policy because it is related to decreasing fertility. To what extent does the development towards less emphasis on pronatalist values come about by cohort replacement and to what extent by intra-cohort changes (period effects)? Before we address our research questions empirically, we first describe some major economic and cultural trends that occurred in the Netherlands since the 1950's, followed by an outline of the research literature and the prevalent ideas on change in values about voluntary childlessness.

\subsection{Economic and Cultural Modernization in the Netherlands}

Between the 1950s and the 1970's the Netherlands experienced a strong modernization process, of which we here highlight some important aspects. First, average income increased rapidly. The development of the Gross National Product per capita, expressed in 


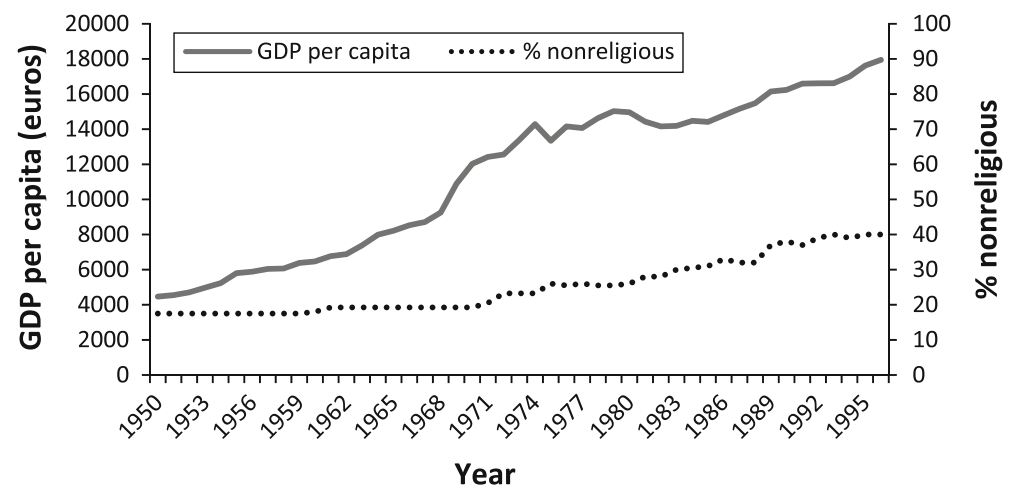

Fig. 2 GDP per capita and the relative number of nonreligious people by year. Source Statistics Netherlands at www.cbs.nl/statline

1999 Euros, shown in Fig. 2, displays this development. In 1950, GNP per capita was 4,470 euro and in 1996 it had increased to 17,950 euro per capita (Statistic Netherlands 2009; own calculations ${ }^{2}$ ). This represents an average growth in income of $3.1 \%$ per year, corrected for inflation.

Second, growing income is often seen as the driving force behind value change (Alwin and Scott 1996; Inglehart 1977; Ryder 1965). Inglehart's theory of value change argues that growing prosperity and the fulfilment of basic material needs make that younger generations started to reject so-called materialist values and moved on to post-materialist values. Important elements of the new value pattern was a focus on personal autonomy, self-actualisation, and tolerant values. Large proportions of the population drifted away from traditional values in the 1960s and 1970s (de Graaf 1988; Inglehart 1977, 1990, 1997). An important part of the cultural modernization process was that sex roles have become less strong. Traditional values about how men and women should lead their lives have eroded, and women got the same rights as men to work on the labour market (van der Lippe 1993).

Third, the process of economic and cultural modernization has gone together with a fast secularization process. The moral guidance of religion in general and of churches and church leaders in particular has come under pressure, and the clash between modern values and the official, pro-family, doctrine of religious ideologies lead to secularization. Figure 2 shows that in $195018 \%$ was non-religious, and that this percentage has increase to $40 \%$ in 1996 (Becker and de Hart 2006). In the same period the proportion of churchgoers (at least monthly) has decreased to less than one fourth of the population.

Fourth, new contraceptive methods, such as oral contraceptives, became available. The invention of the hormonal birth control pill in the 1950s made that parenthood became much more a choice rather than a biological phenomenon (Hakim 2003). Oral contraceptives were introduced in the Netherlands in 1962 and were an immediate success (Rensman 2006). The percentage of women using the birth control pill has risen enormously. In 1962 about 3\% of Dutch women in the relevant age category used the birth control pill. In the 1970s this percentage was about 38\%, and 1996 it was 46\% (Bronsema

\footnotetext{
2 To calculate GNP per capita, we first divided national income by population size. In addition, we also corrected for changes in purchasing power using the Consumer Price Index.
} 
and Moors 1994; Rensman 2006). It is against this background of economic and cultural modernization that we analyse the rapid change in the acceptance of childlessness.

\section{Theoretical Background}

\subsection{Shifts in the Public Acceptance of Childlessness: Cohort Replacement Effects and Intra-Cohort Change}

The first plausible explanation for changing societal acceptance levels of voluntary childlessness is related to cohort membership and the succession of cohorts (Firebaugh 1997). A cohort can be defined as the aggregate of individuals born in a certain period of time (Ryder 1965). Each cohort group experiences different societal events during the socialization stage, i.e. childhood and adolescence (Rodgers 1982). These so-called formative years leave an imprinting stamp on a person's beliefs, values and attitudes (Ryder 1965), as these values reflect the social and economic circumstances in society during socialization (Inglehart 1977) and are assumed to crystallize into stable orientations which become resistant to change (Alwin 1990). This argument assumes that cohort groups differ in their fertility values because they were raised in distinctive historical periods. Research indeed shows that older cohorts tend to be more conservative and traditional (Inglehart 1977, 1990), and therefore are more likely to disapprove of voluntary childlessness. Younger cohorts, on the other hand, hold more liberal and modern views and are more tolerant towards couples who forgo parenthood. In this perspective, social change may occur because of the natural process of cohort replacement. As a consequence of birth, new, more liberal cohorts enter society and replace the older, more traditional ones who die out, leading to a gradual shift in the acceptance of voluntary childlessness. As this process of change happens slowly and steadily Inglehart (1977), called it 'a silent revolution'.

A second source of social change describes a process that may lead to a more revolutionary shift in society, namely through changes within cohorts (intra-cohort effects; Firebaugh 1997). This process refers to attitudinal changes that affect all members present at a certain time in society, regardless of their cohort group (Glenn 1977). When changes in values in response to changes in the macro societal circumstances are not restricted to the young generation but refer to older people as well, this can lead to a rapid change of values in society. It is important to note that this process also implies that people dispose of a lifelong openness to attitude change in contrast to the notion of cohort replacement, which assumes attitudinal stability after young adulthood (Visser and Krosnick 1998).

In this paper, we will estimate the contribution of both cohort replacement effects and intra-cohort change to the shift in acceptance levels of voluntary childlessness in the Netherlands from 1965 till 1996. We hypothesize that intra-cohort effects contribute more to this societal change than cohort replacement effects, as the shift towards higher acceptance levels is very large in the period 1965-1980. Changes related to cohort replacement are simply taking place too slow to account for this rapid attitudinal change. From 1980 onwards, changes in fertility values are less pronounced, which implies that cohort replacement effects could become more important than intra-cohort effects in this period.

\subsection{Who are Intolerant Towards Voluntary Childlessness?}

Given the high public acceptance levels of voluntary childlessness in the 1990s, our second research question is about those who remain intolerant and do not accept voluntary 
childlessness. First, we will look at socio-demographic characteristics. Previous research has found that gender, family structure, educational level, income, and urbanization are linked to fertility values. Women have more positive attitudes towards childlessness than men, presumably because of higher opportunity costs (Koropeckyj-Cox and Pendell 2007; Thornton and Young-DeMarco 2001).

Next to economic costs such as lost wages and career advancement (the so-called "motherhood penalty", (see e.g.: Budig and England 2001), mothers in general are more involved in parenting than fathers, leading to greater personal costs in terms of time commitment, sacrifice and stress (Crittenden 2001). We also expect that people living with a partner and/or children have lower acceptance levels compared to people that are not in a stable relationship or who are childless (Beets et al. 1999).

Furthermore, individuals with higher educational levels and higher socio-economic positions are thought to be more tolerant than less privileged people. Education increases one's "breath of perspective" (Gabennesch 1972, 859) and makes more critical towards traditional values and more open to new ideas and arguments. Finally, people living in urbanized areas are expected to hold more tolerant views, because of the more densely populated and socially heterogeneous environment they live in (cf. Carter and Borch 2005; Wilson 1985). This implies that city-dwellers are more likely to show higher levels of approval of voluntary childlessness than people living in rural communities.

Next to these socio-demographic characteristics, religion seems to be a key factor when explaining fertility behaviour or values (cf. Zhang 2008). Religious ideologies all spread pro-family messages, but the strength of these messages depends on the specific religious doctrine of a denomination. In the Netherlands, three Christian denominations can be distinguished: Roman Catholic, Dutch Reformed (Nederlands Hervormden, generally the more liberal Protestants) and Re-reformed (Gereformeerden, generally the more orthodox Protestants). The Roman Catholic Church propagates a pronatalistic point of view which encourages members to have a large family and is known for its clear statements against contraception and abortion (Pearce 2002; Zhang 2008). This pronatalist doctrine was especially strong in the Netherlands, as Roman Catholics occupied a minority position in Dutch society. After an era of persecution, the Roman Catholic Church was granted equal rights in 1795 and tried to strengthen its institutions and societal position in the 19th and first half of the twentieth century (Barrett et al. 2001). Catholic clergy actively promoted high fertility rates, for example by visiting married couples without children and by campaigning against breastfeeding (cf. Schellekens and Poppel van 2006). In the 1960s, the Dutch Catholic Church tried to modernize in order to keep up with changes in society, but the influence of liberal movements was ended by Vatican appointments of conservative bishops. In 1968, the official doctrine of the Catholic Church with respect to marriage and birth control was reaffirmed in the papal encyclical "Humanae Vitae" (http://en.wikipedia.org/ wiki/Humanae_Vitae).

Strong pronatalist views can also be expected in the group of the Re-reformed, who are divided among several religious communities and churches due to historical schisms (Barrett et al. 2001). These orthodox Protestants see the bible as the infallible word of God, which serves as a strict moral guidance. They strongly believe in God's Providence, which makes that interventions in matters of life and death are unacceptable. The Re-reformed therefore have clear doctrines against contraception and abortion, whereas family life and children are viewed as very important. In addition, the high level of social control in Rereformed communities reinforces religious norms regarding fertility. For example, in regular house calls, family members and delegates of the church talk about religious matters in personal life. 
The largest group of Protestants in the Netherlands, the Dutch Reformed, can be characterized as more liberal when it comes to fertility issues. First of all, liberal Protestants have been associated with rationalist and pragmatic values (cf. McQuillian 1999). The Dutch Reformed are encouraged to take responsibility in handling the problems of everyday life and not rely on traditional doctrine alone (de Loor 1981). In addition, theological multiformity within the Dutch Reformed Church grew since the nineteenth century (de Loor 1981), which makes it less obvious for its members to adhere to one official doctrine. This pattern is strengthened by the internal structure of the Dutch Reformed Church, which is less hierarchical and more democratic than for example in the Roman Catholic Church. Furthermore, in order to read the bible thoroughly, the Dutch Reformed place great emphasis on literacy and education, which gives way to more tolerant views. Finally van Bavel and Kok (2005), mention that the Dutch Reformed see marriage as a bond with mutual support between spouses, which gives room for discussion about birth control.

We expect these religiosity effects to work in several ways. First, people who were raised and socialized in a Roman Catholic, Re-reformed, or Dutch Reformed context, should be affected by the way their church thinks about fertility issues, even if they later in life left their religious denomination. We expect that they are less tolerant towards voluntary childlessness than individuals who were not socialized religiously, and within the group of religiously socialized, that those who were raised in a Roman Catholic or Rereformed environment are less tolerant than those socialized in a Dutch Reformed context. The same parallel can be drawn for current religious membership. Individuals not belonging to a denomination are expected to show the highest levels of acceptance of voluntary childlessness, whereas the Dutch Reformed are thought to be more tolerant than Roman Catholics and Re-reformed. These denomination effects are expected to be stronger for those visiting religious institutions regularly. Churches create the opportunity to meet other people with the same religious background. Therefore, visiting religious services stimulates social interaction with people adhering to similar religious ideas. These closeknit networks will further strengthen religious norms regarding fertility. As a consequence, members will adopt the fertility behaviour patterns and values displayed by their network (Zhang 2008).

\section{Data}

To answer our research questions, we use thirteen waves of the Cultural Change in the Netherlands (CCN) survey (Social and Cultural Planning Office 1996). The CCN data were collected in 1965, 1970, 1975, 1980, 1983, 1985, 1987, 1991, 1992, 1993, 1994, 1995, and 1996, and consist of national representative surveys of Dutch adults age 17 and over. The $\mathrm{CCN}$ surveys contain information on values related to politics, social policy, work, and family, and enable us to construct a rich and highly comparable sample, since no changes in survey design or wording of questions were made during the period 1965-1996. The number of respondents ranges from 1,517 to 2,418 per year. Our aggregate sample consists of respondents, and 24,016 respondents have valid data on all variables.

Our main variable of interest is the acceptance of voluntary childlessness. It is measured by the item: 'A married couple decides to not have children, while there are no medical restrictions. Do you approve or disapprove?' with answer categories (1) 'approve', (2) 'it depends (on circumstances)', and (3) 'do not approve'. Table 1 shows that unconditioned approval of childlessness has increased by more than 67\% in the period 1965-1996. In 


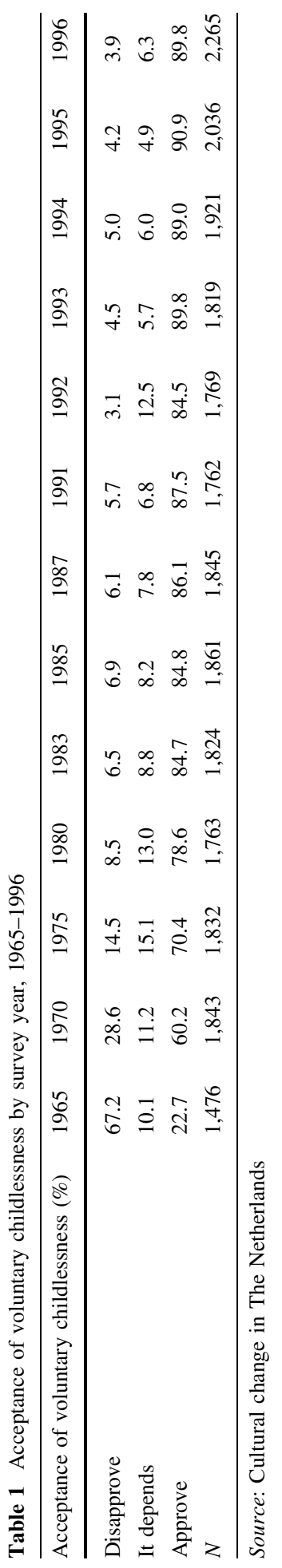


1965, 23\% tolerated childlessness without further consideration of the circumstances; in 1996 this figure had risen to $90 \%$. As Fig. 1 showed, most of the change in acceptance of voluntary childlessness has occurred between 1965 and 1980, in the beginning of our observation window. A closer examination of the data shows that respondents became more pronounced in their approval of couples who decide to forgo parenthood. People in the 1980s and 1990s either approved or disapproved of childlessness, because on average the portion of respondents in the 'it depends' category is larger at the beginning and smaller at the end of the time span of our trend analysis. In 1996, it seems that nowadays a vast majority in the Netherlands approves voluntary childlessness.

For the analysis of intra-cohort change, we construct thirteen time periods indicating the year of survey. In addition, eight cohort groups are defined to measure cohort replacement effects: respondents born (1) before 1910, (2) 1910-1919, (3) 1920-1929, (4) 1930-1939, (5) 1940-1949, (6) 1950-1959, (7) 1960-1969, and (8) 1970 or later.

\subsection{Individual Characteristics}

In our analysis to answer the research question about the social categories who are (still) not accepting voluntary childlessness, we focus on the last 6 years of the time span in the data: 1991-1996. Appendix gives an overview of the distributions of the individual level explanatory variables. Gender is a dichotomous variable with one indicating women. Partner status is a dichotomous variable indicating whether or not the respondent is in a long-term relationship (i.e. cohabitating or married). The household composition variable refers to respondent's current household composition, i.e. the number of children living with the respondent at the time of the survey. This makes is difficult to compare people with and without children, because respondents not living with a child at the time of the survey can either be childless or in the empty nest stage. Therefore, we subdivide respondents not living with at least one child in two age groups. Respondents older than 40 are assumed to have children and to be in the empty nest stage, whereas younger individuals (age 40 at most) are thought to have not entered parenthood yet. Unfortunately, both age groups will include respondents who never had or will have children, but our data has no indicator for this. This means that household composition is measured in four categories, namely (1) 'no children, respondent is forty at most', (2) 'no children; respondent is older than forty', (3) 'one or two child(ren)' and (4) 'three or more children'. Educational level is divided into four categories; (1) primary education and lower vocational education, (2) lower secondary education, (3) higher secondary education and middle vocational education and (4) university or higher vocational education. Income is measured as the logged annual gross household income in Dutch guilders and is corrected for inflation rates. Finally, urbanization is coded as an indicator with one referring to a resident of one of the three largest cities in the Netherlands, namely Amsterdam, Rotterdam, or The Hague. Religious socialization is measured by asking respondents whether they were raised and socialized with a specific religious belief. Religious denomination is assessed with the question: 'Do you consider yourself as belonging to a religious denomination?' Both religious socialization and denomination are coded in five categories: (1) none, (2) Roman Catholic, (3) Dutch Reformed, (4) Re-reformed and (5) Other. ${ }^{3}$ Church attendance is measured by the question 'How often do you usually (e.g. last

\footnotetext{
3 Although the surveys give no further information on other denominations, national statistics show that these predominantly consist of other Christians such as Pentecostals and Jehovah's witnesses, and-to a lesser extent-Muslims (Barrett et al. 2001).
} 
6 months) attend church?' Respondents are divided in two categories, namely those attending church once a month or more often, and those who visit church never or less than once a month.

\subsection{Analytic Strategy}

To answer our first research question, which focuses on the major sources of change in public support for voluntary childlessness, we assess intra-cohort and cohort replacement effects using the repeated cross-sectional $\mathrm{CCN}$ data ${ }^{4}$ in two steps. First, we estimate net intra-cohort and cohort replacement effects by including survey year and cohort groups in a multinomial logistic regression analysis: $y=b_{0}+b_{1}$ year $+b_{2}$ cohort $+e$. This step will also show whether intra-cohort change is linear and additive, a prerequisite for our second step, in which we use the slopes of the aforementioned equation to calculate the relative importance of both sources of social change (Firebaugh 1997). In this linear decomposition, the contribution of intra-cohort change is measured by the formula $b_{1}\left(\mathrm{Y} R_{\mathrm{t}}-\mathrm{Y} R_{1}\right)$. The term between brackets represents the number of years between the first and the final wave of the survey, i.e. $1996-1965=31$ in our data. The coefficient $b_{1}$ refers to intracohort change per year. Thus, by multiplying $b_{1}$ with the total number of survey years in our sample, the total or relative contribution of intra-cohort change can be obtained. For estimating cohort replacement, we use the formula $b_{2}\left(C_{\mathrm{t}}-C_{1}\right)$, with $b_{2}$ indicating the change in acceptance of voluntary childlessness per birth year. $\left(C_{\mathrm{t}}-C_{1}\right)$ refers to the difference in the average of birth years in the 1965 survey and the average of birth years in the 1996 survey.

To answer our second research question about which respondents nowadays are intolerant of voluntary childlessness in a tolerant society, individual level variables are included in a multinomial logistic regression model for the survey years 1991-1996.

\section{Results}

\subsection{Main Sources of Social Change}

Table 2 presents the results of our base line multinomial logistic regression model. Model 1 includes only the survey years as a predictor variable, and in Model 2 birth cohort is added. Model 1 repeats the results which were already visible in Fig. 1 and Table 1: There has been a strong increase in the acceptance of voluntary childlessness. Model 2 is more interestingly: The results show that there are strong period and cohort effects with regard to the acceptance of voluntary childlessness, and that the differences between the survey years are only partially explained by the inclusion of birth cohort in the regression equation. We observe that the rise in acceptance of childlessness is most prominent

\footnotetext{
${ }^{4}$ Firebaugh (1997) argues that the analysis of repeated cross-sectional data can only serve as a tool to identify intra-cohort change and cohort replacement effects, if change within birth cohorts is not due to a changing composition of the population as caused by mortality and migration. Migration can be assumed to be of little consequence since Dutch immigration as well as emigration levels are less than one percent of the total population in the period 1900-1996 (Statistics Netherlands at www.cbs.nl/statline). Mortality is correlated with educational attainment and gender. Since the (probably) more tolerant groups (the high educated and women) survive the less tolerant groups the negative effect of cohorts may be overestimated, which means that the proportion of the total change that is attributed to intra-cohort change is overestimated to an unknown extent.
} 
Table 2 Multinomial logistic regression analysis on acceptance of voluntary childlessness: Net intra-cohort and cohort replacement effects, 1965-1996

\begin{tabular}{|c|c|c|c|c|}
\hline & \multicolumn{2}{|l|}{ Model 1} & \multicolumn{2}{|l|}{ Model 2} \\
\hline & $\begin{array}{l}\text { Unacceptable vs } \\
\text { acceptable }\end{array}$ & $\begin{array}{l}\text { It depends vs } \\
\text { acceptable }\end{array}$ & $\begin{array}{l}\text { Unacceptable vs } \\
\text { acceptable }\end{array}$ & $\begin{array}{l}\text { It depends vs } \\
\text { acceptable }\end{array}$ \\
\hline \multicolumn{5}{|c|}{ Survey year (ref: 1965) } \\
\hline 1970 & $-1.830 * * *$ & $-.868^{* * *}$ & $-1.696 * * *$ & $-.767 * * *$ \\
\hline 1975 & $-2.668 * * *$ & $-.728 * * *$ & $-2.478 * * *$ & $-.582 * * *$ \\
\hline 1980 & $-3.315^{* * *}$ & $-.990 * * *$ & $-2.970 * * *$ & $-.740 * * *$ \\
\hline 1983 & $-3.649 * * *$ & $-1.457 * * *$ & $-3.233 * * *$ & $-1.164 * * *$ \\
\hline 1985 & $-3.590 * * *$ & $-1.524 * * *$ & $-3.098 * * *$ & $-1.184 * * *$ \\
\hline 1987 & $-3.728 * * *$ & $-1.590 * * *$ & $-3.188 * * *$ & $-1.230 * * *$ \\
\hline 1991 & $-3.811 * * *$ & $-1.752 * * *$ & $-3.192 * * *$ & $-1.358 * * *$ \\
\hline 1992 & $-4.406^{* * *}$ & $-1.101 * * *$ & $-3.754 * * *$ & $-.690 * * *$ \\
\hline 1993 & $-4.090 * * *$ & $-1.944 * * *$ & $-3.418 * * *$ & $-1.524 * * *$ \\
\hline 1994 & $-3.955^{* * *}$ & $-1.889 * * *$ & $-3.271 * * *$ & $-1.467 * * *$ \\
\hline 1995 & $-4.155^{* * *}$ & $-2.118 * * *$ & $-3.455^{* * *}$ & $-1.688 * * *$ \\
\hline 1996 & $-4.214 * * *$ & $-1.844 * * *$ & $-3.522 * * *$ & $-1.421 * * *$ \\
\hline \multicolumn{5}{|c|}{ Cohort (ref: <1910) } \\
\hline 1910-1919 & & & $-.288 * * *$ & -.204 \\
\hline 1920-1929 & & & $-.562 * * *$ & $-.298 * *$ \\
\hline 1930-1939 & & & $-.729 * * *$ & $-.475 * * *$ \\
\hline 1940-1949 & & & $-1.310 * * *$ & $-1.009 * * *$ \\
\hline 1950-1959 & & & $-1.692 * * *$ & $-1.178 * * *$ \\
\hline 1960-1969 & & & $-1.778 * * *$ & $-1.117 * * *$ \\
\hline$>=1970$ & & & $-1.677 * * *$ & $-.858 * * *$ \\
\hline $\mathrm{Chi}^{2}(d f)$ & $4,393(24)$ & & $5,063(38)$ & \\
\hline$N$ & 24,016 & & 24,016 & \\
\hline
\end{tabular}

Source: Cultural change in The Netherlands

$* p<0.10$; ** $p<0.05$; *** $p<0.01$

between 1965 and 1975. The level of acceptance has increased after 1975 as well but with a far lower momentum than before. In addition, Table 2 reveals that younger birth cohorts have stronger acceptance than older cohorts.

Our base line regression models makes clear that there are both intra-cohort and cohort replacement effects at work. But which one is more dominant in explaining the cultural shift towards more acceptance of voluntary childlessness? In order to find out the relative contribution of intra-cohort and cohort replacement effects, we use the linear decomposition method proposed by Firebaugh (1997). First, we have to determine whether the linear-additive assumption underlying this method is appropriate for our set of intra-cohort and cohort replacement variables. Based on the multinomial logistic regression results shown in Table 2, it can be concluded that there is no clear linear relationship between acceptance levels of voluntary childlessness and survey year over the whole period 19651995, but that there are two sub-periods in which the relationship is linear. Between 1965 and 1980 there has been a sharp increase in acceptance levels, whereas the period between 1983 and 1996 there has been a more moderate increase. 
Table 3 presents the results of the linear decomposition for the total period (19651996) and for the two sub-periods 1965-1980 and 1983-1995 separately. We focus on the difference between the 'acceptable' and the 'unacceptable' category, as here the shifts are most pronounced. The upper part of the table shows the multinomial logistic regression results on which the calculations in the lower part of the table are based. These calculations yield striking results. Almost $90 \%$ of the change in acceptance of voluntary childlessness between 1965 and 1980 stems from intra-cohort change, whereas cohort replacement seems to be of less importance. The second time period, starting from 1983 and ending in 1996, shows a reversed pattern with cohort replacement effects overshadowing intra-cohort change (64\% vs. 36\%). Here, shifts in fertility values are mainly due to the replacement of older, more conservative cohort groups with younger, more tolerant ones.

\subsection{Determinants of Intolerance}

So far, we focused on the enormous increase in tolerance towards voluntary childlessness and the main causes of this growth. At this point, the question rises which members of society are intolerant, since our results suggest that permissiveness regarding childlessness has dominated Dutch society since the 1990s. Approximately $90 \%$ of the Dutch population unconditionally approves a couple's decision to forgo parenthood. Table 4 gives the multinomial logistic regression results for the period 1991-1996. We focus on the coefficients in the left column, where the two most extreme answer categories are compared. First, we see that in the 1990s birth cohort still is of considerable importance after controlling for other individual level characteristics. People who were born before 1940 show lower levels of acceptance than those who were born before that moment in time.

When looking at the socio-demographic variables, we see that women do not seem to be more tolerant towards couple's fertility decisions than men are. In addition, having a partner or not does not affect one's view on voluntary childlessness, but having children does. Living with three or more children leads to higher levels of disapproval in comparison to respondents living with no, one, or two children. In addition, the higher educated show lower levels of disapproving childlessness than the lower educated. People with a higher income are more tolerant towards voluntary childlessness as well. Finally, living in one of the three largest cities in the Netherlands (Amsterdam, Rotterdam or The Hague) has no significant effect on the chance of approving childlessness.

When we turn our focus to religion, we see that religious socialization increases one's negative attitudes toward childlessness only for respondents who were brought up with the religious ideas of other denominations than the three large ones in the Netherlands. Contrary to what we expected, people socialized in a Roman Catholic, Dutch Reformed, or Re-reformed environment do not have higher chances of rejecting childlessness compared to those who are not religiously socialized. Of course, these zero effects are only present in a model that controls for current religiosity and for current church attendance, but it is remarkable that religious socialization does not have an additional impact on values that are so directly related to religious doctrines.

When we turn to current religiosity we observe that persons who say they have a religious denomination but who do not attend church services regularly are not less 


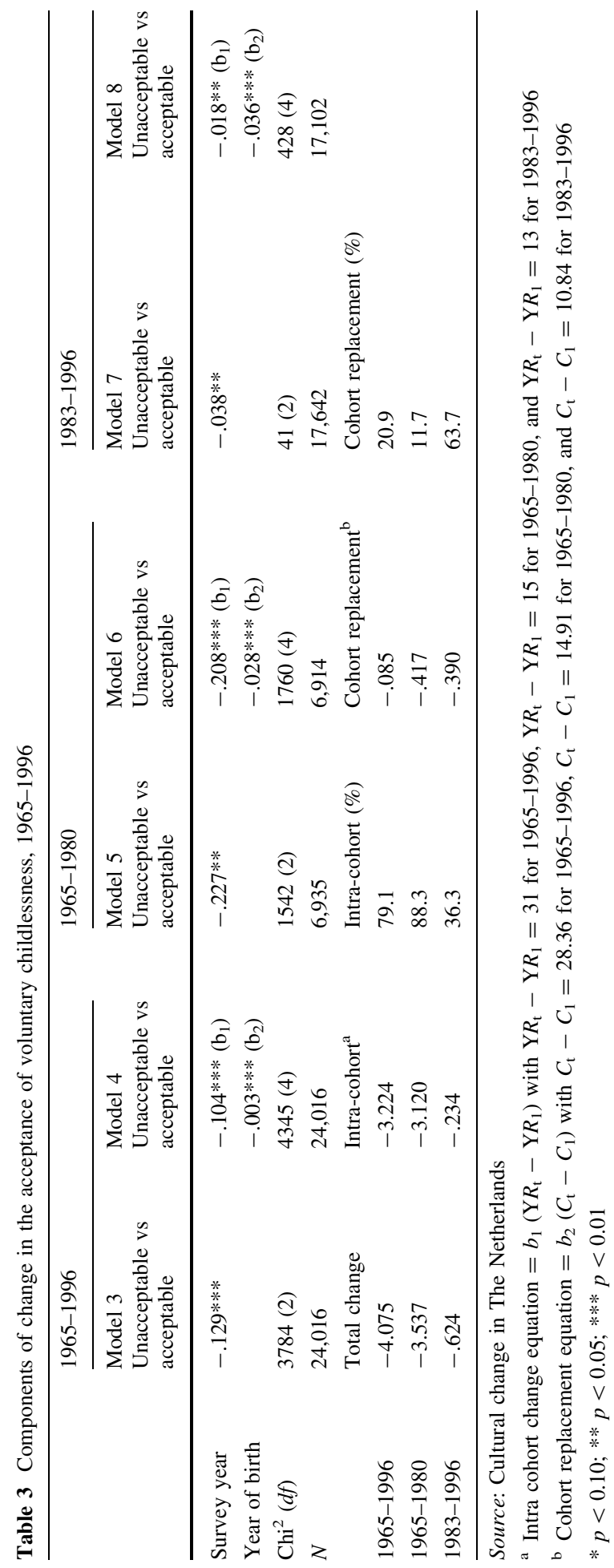


Table 4 Multinomial logistic regression analysis on acceptance of voluntary childlessness: Effects of individual characteristics, 1991-1996

\section{Model 12}

Unacceptable vs acceptable It depends vs acceptable

Cohort (ref: 1910-1919)

$1920-1929$
$1930-1939$
$1940-1949$
$1950-1959$
$1960-1969$
$>=1970$

$-.348$

.006

$-.413$

$-1.230 * * *$

$-.359$

$-1.616^{* * *}$

$-.682 * *$

$-1.169 * * *$

$-.465$

$-.991 * *$

$-.173$

Gender (ref: men)

Women

$-.299$

$-.090$

Partner status (ref: no partner)

Partner

Household composition (ref: 1 or 2 child(ren))

No children $>40$ years

$-.037$

$-.065$

No children $<=40$ years

$-.228$

.006

3 or more children

$.619 * * *$

$.337 * *$

Educational level (ref: primary education)

Lower secondary/vocational education

Higher secondary/vocational education

$-.675 * * *$

$-.384 * * *$

$-1.069 * * *$

$-.796 * * *$

University

$-.994 * * *$

$-1.289 * * *$

Income

Logged annual gross household income

$-.532 * * *$

$-.553 * * *$

Urbanization (ref: not living in three largest cities)

Living in three largest cities

$-.228$

Religious socialization (ref: none)

Roman Catholic

.094

$-.122$

Dutch Reformed

.601

Re-reformed

$1.054 * * *$

Other

Religious denomination $\times$ church attendance (ref: none)
Roman Catholic $\times$ no regular church attendance $\quad .281$

Roman Catholic $\times$ regular church attendance

$.830^{* * *}$

$1.402 * * *$

Dutch Reformed $\times$ no regular church attendance

$.397 *$

Dutch Reformed $\times$ regular church attendance

$1.079 * * *$

$1.082 * * *$

Re-reformed $\times$ no regular church attendance

$-.548$

$.675^{* *}$

Re-reformed $\times$ regular church attendance

$1.783 * * *$

$1.219^{* * *}$

Other $\times$ no regular church attendance

.789

.475

Other $\times$ regular church attendance

1.476 ***

$.960^{* * * *}$

$\mathrm{Chi}^{2}(d f)$

1,071 (58)

N

10,782

Source: Cultural change in The Netherlands

$* p<0.10$;** $p<0.05$;** $p<0.01$ 
Table 5 Acceptance levels (\%) by church attendance and educational attainment, CCN 1991-1996)

\begin{tabular}{lcccc}
\hline & Do not approve & It depends & Accept & Total \\
\hline No regular church attendance & & & \\
Lower educated & $34.9(174)$ & $44.5(342)$ & $47.4(4758)$ & $46.7(5274)$ \\
Higher educated & $7.8(39)$ & $10.0(77)$ & $32.0(3216)$ & $29.5(3332)$ \\
Regular church attendance & & & $16.7(1885)$ \\
Lower educated & $46.4(231)$ & $35.5(273)$ & $13.8(1381)$ & $7.2(814)$ \\
Higher educated & $10.8(54)$ & $9.9(76)$ & $6.8(684)$ & $100(11.305)$ \\
Total & $100(498)$ & $100(768)$ & $100(10.0039)$ & 1000 \\
\hline
\end{tabular}

Source: Cultural changes in the Netherlands (CCN), 1991-1996

tolerant when it comes to fertility values than non-religious people ${ }^{5}$. This holds for Roman Catholics, Dutch Reformed, Re-reformed, as well as individuals belonging to other denominations. However, when people who belong to a religious denomination visit church at least once a month, they exhibit significant lower acceptance levels of voluntary childlessness. This pattern is particularly strong for the Re-reformed, as might be expected, and less pronounced for Roman Catholics.

In sum, religiosity is clearly related to one's view regarding voluntary childlessness. It appears that church attendance makes the difference: Those attending religious services regularly report lower levels of acceptance compared to those not visiting church on a regular basis. When examining acceptance levels between 1991 and 1996, we find that more than half of those disapproving childlessness visits church often. Table 5 also reveals that educational level is related to one's view regarding childlessness since the lower educated are more likely to disapprove childlessness than the higher educated.

\section{Summary and Conclusions}

First, the Cultural Change in the Netherlands data reveals an enormous increase in tolerance towards childlessness. In 1965, less than one in four respondents accepted childlessness without further consideration of the circumstances, while this percentage approaches $90 \%$ in 1996. Furthermore, to explain growing acceptance of childlessness, we focused on intracohort and cohort replacement effects. The analyses yield several interesting results.

With respect to the results of the linear decomposition, it can be concluded that changes within cohorts are mainly responsible for the shift in the acceptance of childlessness between 1965 and 1980. The change in public opinion regarding childlessness in this period is not so much caused by replacement or succession of different groups within society. Instead, members within existing groups (cohorts) changed their fertility values due to specific factors of a contextual nature that affected all members of society (i.e. period effects), and this caused a decrease in the rejection of childlessness at the national level. For clarifying the change in acceptance of childlessness between 1983 and 1996 a different explanation applies. Here, the increase in acceptance is mainly due to

\footnotetext{
5 Roman Catholics, Dutch Reformed, Re-reformed, and those belonging to other religious denominations are more likely than non-religious people to answer "it depends (on circumstances)" rather than "acceptable" when it asked about voluntary childlessness. Apparently, the first group has more reservations when it comes to approving of a couple's decision to forgo parenthood. This pattern is strengthened by attending church regularly. However, since our focus is on the intolerant in a tolerant society, we do not discuss these results in detail.
} 
replacement of older, more conservative cohorts by younger, more tolerant cohorts, referring to the changing composition of society.

We conclude that the dramatic change in the acceptance of voluntary childlessness is part of the major changes that took place in the Netherlands in the sixties and seventies, before levelling off during the eighties and nineties. These economic and demographic macro mechanisms work in two ways: first, by influencing values on voluntary childlessness during socialization (cohort replacement effect) and by influencing these values later in life (intra-cohort change).

Because of high acceptance levels at the end of our survey period (1991-1996), the question rises who remains intolerant in a tolerant society. As expected, respondents with three or more children and those with lower socio-economic positions (lower education and income levels) show higher chances of disapproving voluntary childlessness. Gender, partner status, and urbanization do not affect people's fertility values. Furthermore, we find that religion is an importance predictor of permissiveness, although its effects are less pronounced than we anticipated. For example, we observe hardly any influence of being brought up within a religious context. In addition, members of a religious denomination do not per se exhibit lower chances of accepting voluntary childlessness than non-religious people. It is church attendance that seems to be the key factor when it comes to explaining fertility values. Members of a religious denomination who attend church services once a month or more have higher levels of disfavouring voluntary childlessness, and members who do not visit church regularly on average have the same values as the non-religious. The significance of church attendance cannot be overstated. By visiting church, religious people are exposed to the pro-family messages of religious denominations more extensively and more frequently. This pattern is most pronounced for the Re-reformed, for who we anticipated strong pronatalist views in the first place.

Although this study has shed more light on the causes of changing fertility values, this article also leads to suggestions for future research. First, the CCN survey does not provide any information on the acceptance of childlessness from 1996 onwards. It is not very likely that the percentage of the Dutch population who accept voluntary childlessness will further increase, given the high level at the end of our time span. However, it would be interesting to assess whether a counter trend towards more conservative fertility values emerged. Our finding that the youngest two cohorts (born in 1960 or later) are less tolerant towards voluntary childlessness than the cohorts born earlier points in this direction. In addition, a counter trend has been found in the Netherlands for other values, such as sexual permissiveness (Kraaykamp 2002).

Second, the results in this study should be interpreted with caution because of social desirability. Although it is quite unlikely that the observed radical change in acceptance of voluntary childlessness in the Netherlands can be accounted for by changing perceptions about social desirability_norms about desirability only change unless values are also changing (Firebaugh 1997) — our results might be biased due to the fact that respondents have the tendency to give answers that are compatible with norms in society. Our sample may thus have reported to be more tolerant in fertility values than they actually are. The question rises whether respondents will still be as tolerant towards childlessness if it takes place in their own environment, for instance when close family members decide to have no children. Will parents disapprove their children's decision to forgo parenthood? This is why future research should focus more on the impact of social networks on individual's childbearing dispositions and on actual fertility.

Open Access This article is distributed under the terms of the Creative Commons Attribution Noncommercial License which permits any noncommercial use, distribution, and reproduction in any medium, provided the original author(s) and source are credited. 


\section{Appendix}

See Table 6

Table 6 Descriptive statistics, 1991-1996 $(n=10,782)$

\begin{tabular}{|c|c|c|}
\hline & Mean & S.D. \\
\hline \multicolumn{3}{|l|}{ Cohort $(1 / 0)$} \\
\hline 1910-1919 & 0.01 & \\
\hline 1920-1929 & 0.10 & \\
\hline 1930-1939 & 0.13 & \\
\hline 1940-1949 & 0.17 & \\
\hline $1950-1959$ & 0.25 & \\
\hline 1960-1969 & 0.21 & \\
\hline$>=1970$ & 0.13 & \\
\hline \multicolumn{3}{|l|}{ Gender $(1 / 0)$} \\
\hline Women & 0.55 & \\
\hline \multicolumn{3}{|l|}{ Partner status $(1 / 0)$} \\
\hline Respondent has partner & 0.67 & \\
\hline \multicolumn{3}{|l|}{ Household composition $(1 / 0)$} \\
\hline 1 or 2 child(ren) & 0.41 & \\
\hline No children $>40$ years & 0.30 & \\
\hline No children $<=40$ years & 0.19 & \\
\hline 3 or more children & 0.10 & \\
\hline \multicolumn{3}{|l|}{ Educational level (1/0) } \\
\hline Primary education & 0.32 & \\
\hline Lower secondary/vocational education & 0.32 & \\
\hline Higher secondary/vocational education & 0.23 & \\
\hline University & 013 & \\
\hline \multicolumn{3}{|l|}{ Income (in Dutch guilders) } \\
\hline Annual gross household income & 66,476 & 35,380 \\
\hline \multicolumn{3}{|l|}{ Urbanization $(1 / 0)$} \\
\hline Living in three largest cities & 0.13 & \\
\hline \multicolumn{3}{|l|}{ Religious socialization (1/0) } \\
\hline None & 0.29 & \\
\hline Roman Catholic & 0.39 & \\
\hline Dutch Reformed & 0.19 & \\
\hline Re-reformed & 0.10 & \\
\hline Other & 0.03 & \\
\hline \multicolumn{3}{|l|}{ Religious denomination $(1 / 0)$} \\
\hline None & 0.61 & \\
\hline Roman Catholic & 0.21 & \\
\hline Dutch Reformed & 0.10 & \\
\hline Re-reformed & 0.07 & \\
\hline Other & 0.02 & \\
\hline \multicolumn{3}{|l|}{ Church attendance $(1 / 0)$} \\
\hline On a regular basis & 0.24 & \\
\hline
\end{tabular}




\section{References}

Alwin, D. (1990). Cohort replacement and changes in parental socialization values. Journal of Marriage and Family, 52, 347-360.

Alwin, D., \& Scott, J. (1996). Attitude change: Its measurement and interpretation using longitudinal surveys. In B. Taylor \& K. Thomson (Eds.), Understanding change in social attitudes (pp. 75-106). Dartmouth, U.K: Aldershot.

Barrett, D., Kurian, G., \& Johnson, T. (2001). World Christian Encyclopaedia: A comparative survey of churches and religions in the modern world. Oxford: Oxford University Press.

Becker, J., \& de Hart, J. (2006). Godsdienstige veranderingen in Nederland [Religious changes in the Netherlands]. The Hague.

Beets, G., Liefbroer, A., \& Gierveld, J. (1999). Changes in fertility values and behaviour: A life course perspective. In R. Leete (Ed.), Dynamics of values in fertility change (pp. 100-120). Oxford: Oxford University Press.

Bronsema, H., \& Moors, H. (1994). Ruim dertig jaar pilgebruik [More than thirty years of oral contraceptive use]. Demos, 10(6), 47-48.

Budig, M., \& England, P. (2001). The wage penalty for motherhood. American Sociological Review, 66, 204-225.

Carter, J. S., \& Borch, C. A. (2005). Assessing the effects of urbanism and regionalism on gender-role attitudes. Sociological Inquiry, 75, 548-563.

Castles, F. (2003). The world upside down: Below replacement fertility, changing preferences and familyfriendly public policy in 21 OECD countries. Journal of European Social Policy, 13(3), 209-227.

Crittenden, A. (2001). The price of motherhood: Why the most important job in the world is still the least valued. New York: Metropolitan.

de Graaf, N. D. (1988). Postmaterialism and the stratification process: An international comparison. Utrecht: University of Utrecht.

de Loor, H. (1981). Nederlandse Hervormde Kerk: Terugtocht of aftocht? [Dutch Reformed church: Retreat or withdrawal]. Idem, (67), 61-89.

Dykstra, P., \& Hagestad, G. (2007). Roads less taken: Developing a nuanced view of older adults without children. Journal of Family Issues, 28(10), 1275-1310.

Firebaugh, G. (1997). Analyzing repeated surveys. CA: Thousand Oaks.

Gabennesch, H. (1972). Authoritarianism as world view. American Journal of Sociology, 77, 857-875.

Glenn, N. (1977). Cohort analysis. London: Sage.

Hakim, C. (2003). A new approach to explaining fertility patterns: Preference theory. Population and Development Review, 29(3), 349-374.

Inglehart, R. (1977). The silent revolution: Changing values and political styles among Western publics. Princeton: Princeton University Press.

Inglehart, R. (1990). Culture shift in advanced industrial society. Princeton: Princeton University Press.

Inglehart, R. (1997). Modernization and postmodernization. Princeton: Princeton University Press.

Keizer, R., Dykstra, P., \& Jansen, M. (2007). Pathways into childlessness: Evidence of gendered life course dynamics. Journal of Biosociological Science, 40, 1-16.

Koropeckyj-Cox, T., \& Call, V. (2007). Characteristics of older childless persons and parents. Journal of Family Issues, 28(10), 1362-1414.

Koropeckyj-Cox, T., \& Pendell, G. (2007). The gender gap in attitudes about childlessness in the United States. Journal of Marriage and Family, 69, 899-915.

Kraaykamp, G. (2002). Trends and countertrends in sexual permissiveness: Three decades of attitude change in the Netherlands 1965-1995. Journal of Marriage and Family, 64, 225-239.

Lesthaeghe, R. (1995). The second demographic transition: An interpretation. In K. Oppenheimer \& A. Jensen (Eds.), Gender, family change in industrialized countries (pp. 17-62). Oxford: Clarendon Press.

McQuillian, K. (1999). Culture, religion and demographic behaviour. Catholics and Lutherans in Alsace, 1750-1870. Montreal: McGill-Queen's University Press.

Moors, G. (1996). Gezinsvorming en processen van waardenselectie en -aanpassing [Family formation and processes of value selection - and adaption]. Mens \& Maatschappij, 71(1), 4-24.

Pearce, L. (2002). The influence of early life course religious exposure on young adults' dispositions toward childbearing. Journal for the Scientific Study of Religion, 41(2), 325-340.

Rensman, E. (2006). De pil in Nederland. Een mentaliteitsgeschiedenis [Birth Controll Pill in The Netherlands: History of a mentality]. Amsterdam: Athenaeum-Polak \& Van Gennip. 
Rodgers, W. (1982). Estimable functions of age, period and cohort effects. American Sociological Review, 47, 774-787.

Ryder, N. (1965). The cohort as a concept in the study of social change. American Sociological Review, 30, 843-861.

Schellekens, J., \& van Poppel, F. (2006). Religious differentials in marital fertility in The Hague (Netherlands) 1860-1909. Population Studies, 60, 23-38.

Social cultural planning office, SCP. (1996). Social and cultural report 1996. Rijswijk: Social and Cultural Planning Office.

Thornton, A., \& Young-DeMarco, L. (2001). Four decades of trends in attitudes toward family issues in the United States: The 1960s through the 1990s. Journal of Marriage and Family, 63, 1009-1037.

van Bavel, J., \& Kok, J. (2005). The role of religion in the Dutch fertility transition: Starting, spacing, and stopping in the heart of the Netherlands, 1845-1945. Continuity and Change, 20(2), 247-263.

van de Kaa, D. (1987). Europe's second demographic transition. Population Bulletin, 42, 1-47.

van der Lippe, T. (1993). Division of labor between men and women. Utrecht: Utrecht University.

Visser, P., \& Krosnick, J. (1998). Development of attitude strength over the life cycle: Surge and decline. Journal of Personality and Social Psychology, 75(6), 1389-1410.

Wilson, T. (1985). Urbanism and tolerance: A test of some hypotheses drawn from Wirth and Stouffer. American Sociological Review, 50, 117-123.

Zhang, L. (2008). Religious affiliation, religiosity, and male and female fertility. Demographic Research, 18, 233-261. 